\title{
Eutrophication and warming effects on long-term variation of zooplankton in Lake Biwa
}

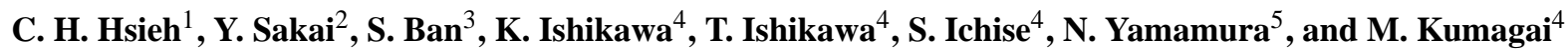 \\ ${ }^{1}$ Institute of Oceanography and Institute of Ecology and Evolutionary Biology, National Taiwan University, \\ No. 1, Sec. 4, Roosevelt Rd. Taipei, 10617, Taiwan \\ ${ }^{2}$ Center for Ecological Research, Kyoto University, Hirano 2-509-3, Otsu, Shiga 520-2113, Japan \\ ${ }^{3}$ School of Environmental Science, the University of Shiga Prefecture, 2500 Hassaka-cho, Hikone, Shiga 522-8533, Japan \\ ${ }^{4}$ Lake Biwa Environmental Research Institute, 5-34 Yanagasaki, Otsu, Shiga 520-0022, Japan \\ ${ }^{5}$ Research Institute for Humanity and Nature, 457-4 Motoyama, Kamigamo, Kita-ku, Kyoto, 603-8047, Japan
}

Received: 10 January 2011 - Published in Biogeosciences Discuss.: 20 January 2011

Revised: 28 April 2011 - Accepted: 1 May 2011 - Published: 30 May 2011

\begin{abstract}
We compiled and analyzed long-term (19612005) zooplankton community data in response to environmental variations in Lake Biwa. Environmental data indicate that Lake Biwa had experienced eutrophication (according to the total phosphorus concentration) in the late 1960s and recovered to a normal trophic status around 1985, and then has exhibited warming since 1990. Total zooplankton abundance showed a significant correlation with total phytoplankton biomass. Following a classic pattern, the cladoceran/calanoid and cyclopoid/calanoid abundance ratio was related positively to eutrophication. The zooplankton community exhibited a significant response to the boom and bust of phytoplankton biomass as a consequence of eutrophication-reoligotriphication and warming. Moreover, our analyses suggest that the Lake Biwa ecosystem exhibited a hierarchical response across trophic levels; that is, higher trophic levels may show a more delayed response or no response to eutrophication than lower ones.

We tested the hypothesis that the phytoplankton community can better explain the variation of the zooplankton community than bulk environmental variables, considering that the phytoplankton community may directly affect the zooplankton succession through predator-prey interactions. Using a variance partition approach, however, we did not find strong evidence to support this hypothesis. We further aggregated zooplankton according to their feeding types (herbivorous, carnivorous, omnivorous, and parasitic) and taxonomic groups, and analyzed the aggregated data. While the
\end{abstract}

Correspondence to: C. H. Hsieh (chsieh@ntu.edu.tw) pattern remains similar, the results are less clear comparing the results based on finely resolved data. Our research suggests that zooplankton can be bio-indicators of environmental changes; however, the efficacy depends on data resolution.

\section{Introduction}

Lakes, due to their vulnerability, have been considered as sentinels of environmental changes, such as anthropogenic effects and global warming (Williamson et al., 2009). For many lakes, one of the most threatening anthropogenic effects is eutrophication (Williamson et al., 2008; Schindler, 2006). Eutrophication has dramatically affected phytoplankton biomass (Dokulil and Teubner, 2005; Horn, 2003; Anneville and Pelletier, 2000) and community (Anneville et al., 2002b; Dokulil and Teubner, 2005) in lakes. To an extreme condition, harmful algal bloom may occur causing severe social-economic costs (Kumagai, 2008; Chen et al., 2003). Eutrophication effects often propagate up to higher trophic levels resulting in changes to the zooplankton community (Anneville et al., 2007; Molinero et al., 2006; Ravera, 1980; Lovik and Kjelliberg, 2003).

In addition to eutrophication, warming in the past half century has also drastically influenced phytoplankton (Winder and Schindler, 2004; Winder et al., 2009a; Hsieh et al., 2010) as well as zooplankton (Molinero et al., 2007; Hampton et al., 2008; Straile, 2000; Benndorf et al., 2001; Nauwerck, 1991) communities in lake ecosystems. Moreover, eutrophication and warming often have synergistic effects on whole lake ecosystems (Wilhelm and Adrian, 2008; Huber et al., 2008; Elliott et al., 2006).

Published by Copernicus Publications on behalf of the European Geosciences Union. 
In this research, we investigated eutrophication and warming effects on the zooplankton community of Lake Biwa. Lake Biwa is the largest lake in Japan; it provides great ecological values, such as high biodiversity and high economic value including transportation, drinking water, and fisheries (Kumagai, 2008). As with many lakes in the world, Lake Biwa has experienced eutrophication and warming through the past several decades. An increase in nutrient loading due to urbanization started in the 1960s, and subsequently blooms of Uroglena americana have occurred since 1977 and cyanobacteria since 1983 (Kumagai, 2008). A water treatment regulation was enforced in 1982, and nutrient loading was progressively reduced and then stabilized after 1985 (Kumagai, 2008). However since late 1980, the air temperature has risen quickly, causing another problem for the Lake Biwa ecosystem (Hsieh et al., 2010). Changes in nutrient and physical conditions due to eutrophication and warming effects and the consequent reorganization of the phytoplankton community in Lake Biwa have been documented (Hsieh et al., 2010). Here, we extend the trophic level upwards and investigate those environmental change effects on the zooplankton community.

In Lake Biwa, zooplankton studies have focused on their role in foodweb dynamics (Nagata and Okamoto, 1988; Urabe et al., 1996; Yoshida et al., 2001a; Kagami et al., 2002) and nutrient cycling (Urabe et al., 1995; Yoshimizu and Urabe, 2002; Yoshimizu et al., 2001; Elser et al., 2001). The seasonal succession of the zooplankton community have been documented (Yoshida et al., 2001b; Miura and Cai, 1990). However, how eutrophication and warming might have affected zooplankton in Lake Biwa for the past half century has rarely been explored. The only exception is the paleo-limnological study by Tsugeki et al. (2003), in which they examined remains of three cladoceran and two rhipod species in a sediment core with a resolution of roughly three years and showed fluctuations of these taxa in the 20th century. They concluded that the increased zooplankton abundance from 1960s to 1980s is likely due to bottom-up effects driven by eutrophication (Tsugeki et al., 2003), and this eutrophicaiton effect has been shown to propagate to fish (Nakazawa et al., 2010). In fact, time series data of the zooplankton community have been collected by the Shiga Prefecture Fisheries Experimental Station (SPFES) since 1962 for fisheries management purposes. Curiously, these data have never been analyzed with respect to environmental variations.

Here, we compiled published records of the zooplankton community by the SPFES. With the environmental and phytoplankton data compiled in Hsieh et al. (2010), we investigated the long-term variation of zooplankton communities in response to eutrophication and warming from 1962 to 2005. Most studies concerning lake zooplankton have focused on daphnids (Wagner and Benndorf, 2007; Benndorf et al., 2001; Straile, 2000; George et al., 1990) and copepods (Seebens et al., 2007; Winder et al., 2009b; Anneville et al.,
2007) and occasionally on rotifers (Molinero et al., 2006). In this research, we investigated environmental effects on the whole mesozooplankton community using a hierarchical manner. First, using the highly resolved taxonomic data (species or genus level), we investigated how eutrophication and warming have driven the reorganization of the zooplankton community. Second, we aggregated the zooplankton data according to their taxonomy (Cladocera, Copepoda, Rotifera, and Protista) or feeding types (herbivorous, carnivorous, omnivorous, and parasitic), because the taxonomy or feeding types may have determined the responses of zooplankton to the changes of their prey field (Kawabata, 1988; Urabe et al., 1996; Yoshida et al., 2001b; Anneville et al., 2007). Such aggregation also allowed us to investigate the effects of data resolution. Third, we examined whether the ratio of cyclopoid/calanoid and of cladoceran/calanoid can be used as an indicator of eutrophication (Ravera, 1980; Kane et al., 2009). Finally, we studied the total zooplankton abundance in response to eutrophication and re-oligotrophication. In addition, we tested the hypothesis in each level of analyses that the phytoplankton community can better explain the variation of zooplankton community than bulk environmental variables (such as total phosphorus, total phytoplankton biomass, or temperature). This hypothesis is based on the observation that changes in the zooplankton community may be critically affected by change in the phytoplankton community through predator-prey interactions and species competitions (Kawabata, 1988; Yoshida et al., 2001b; Polli and Simona, 1992; Magadza, 1994; Anneville et al., 2007).

\section{Materials and methods}

\subsection{Zooplankton data}

Zooplankton samples were collected using a Kitahara's closing net $(139 \mu \mathrm{m}$ in mesh size and $25 \mathrm{~cm}$ in diameter) in four depth intervals ( $0-10 \mathrm{~m}, 10-20 \mathrm{~m}, 20-40 \mathrm{~m}$, and $40-75 \mathrm{~m}$ ) by the Shiga Prefecture Fisheries Experimental Station (SPFES) at five stations (Fig. 1). Numbers of depth intervals varied according to the bathymetry of stations (e.g. only $0-10 \mathrm{~m}$ samples taken in shallow stations 1 and 5). The samples were fixed in 5\% formalin and enumerated under microscopes. While sampling was conducted monthly, zooplankton identification and enumeration was carried out only quarterly for most years. We digitized zooplankton abundance data from published annual reports by the SPFES from 1962 to 2005. For each species, we calculated the depth-integrated zooplankton density $\left(10^{4}\right.$ ind. $\left.\mathrm{m}^{-2}\right)$ for each station, averaged the densities of the five stations into the quarterly mean, and finally averaged the quarterly data into the annual mean. While the seasonality or phenology of zooplankton might also be affected by environmental variations (Anneville et al., 2007), we focused on interannual variation in this study. The taxonomic resolution of zooplankton changed over time and 


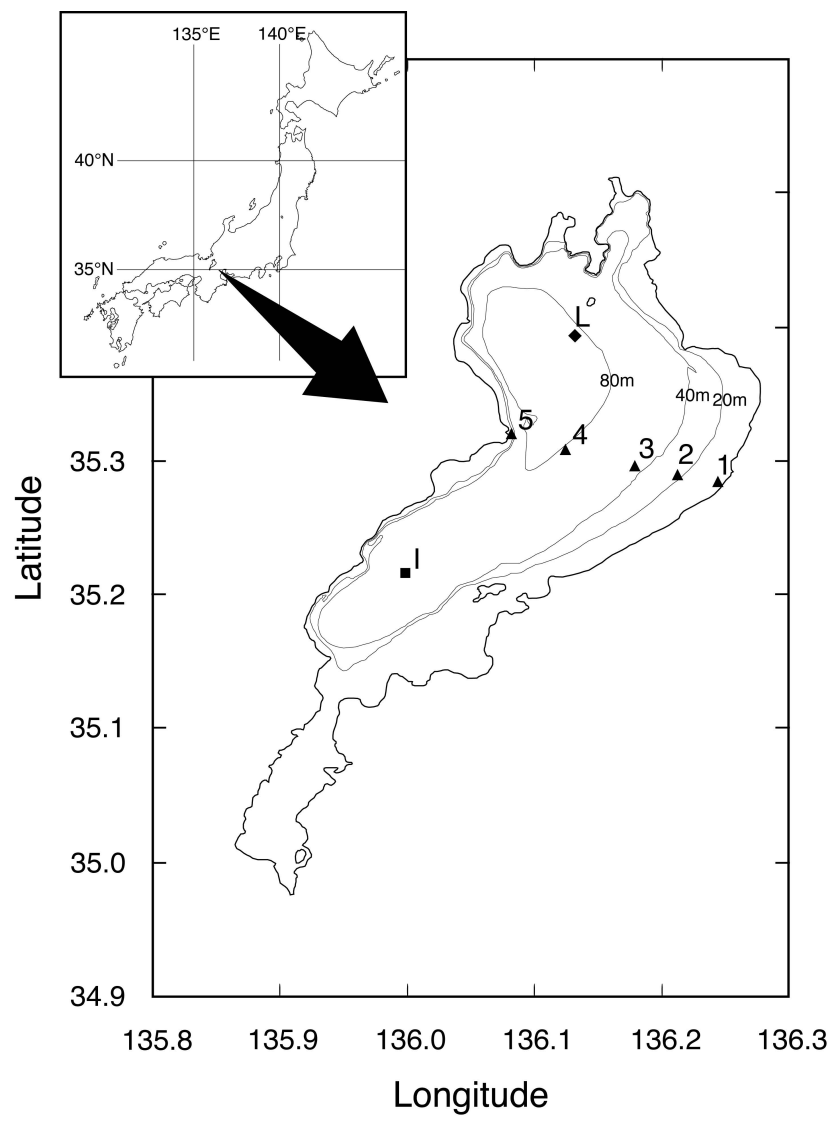

Fig. 1. Map showing sampling stations in Lake Biwa. Stations 1 to 5 are the Shiga Prefecture Fisheries Experimental Stations; station L is the long-term monitoring station of the Lake Biwa Environmental Research Institute; station I is the environmental monitoring station of the Kyoto University.

varied among groups. To ensure consistency, only genuslevel data were obtained for some taxa. Only the taxa occurring in $\geq 15 \mathrm{yr}$ of the 44 sampling years were investigated for this study, which amounted to a total of 20 taxa (6 species and 14 genera, Fig. 2). The only exception is the total zooplankton abundance, which consists of all zooplankton. To simplify this, we call the species/genus resolved dataset "genus data" hereafter. Note that among these 20 taxa, Trichodina spp. is parasitic on aquatic animals and were often collected by plankton nets. We compared our data with that reported by Miura and Cai (1990) from 1965 to 1979 (visual investigation on their figures) and found generally a close agreement, although their zooplankton samples were collected from station I (Fig. 1).

\subsection{Environmental and phytoplankton data}

The details of environmental and phytoplankton data can be found in Hsieh et al. (2010). Here, we focused only on environmental data directly representing water warming and changes in trophic status in Lake Biwa. Lake surface water temperature data (average of 0-20 m) were obtained from SPFES for the same sampling stations (Fig. 1). The surface water temperature exhibited substantial interannual fluctuations superimposed on a long-term increasing trend (Fig. 3a). The average total phosphorus (TP) in the upper $20 \mathrm{~m}$ was used to represent the trophic status of the Lake (see Hsieh et al., 2010 for data source). The TP increased quickly after 1967, reached a maximum in 1974 and then declined until 1985, and fluctuated around a stable value thereafter (Fig. 3b). In addition to the local environmental data, climate indices were included in the analyses. We investigated the Arctic Oscillation index (AO), a climate pattern that has been known to influence the weather condition of Japan (Thompson and Wallace, 1998). The air and water temperatures of Lake Biwa were significantly related to the AO index (Hsieh et al., 2010). We investigated also the Pacific Decal Oscillation (PDO) (Mantua et al., 1997) and Southern Oscillation index (SOI) (Trenberth, 1984). These basin-scale patterns have been shown to influence the climate of Japan through air-sea interactions (Miyazaki and Yasunari, 2008; Jin et al., 2005). Their influences on marine zooplankton have been studied (Chiba et al., 2006); however, their effects on the lakes of Japan are not clear.

Phytoplankton community data include the time series from 1978 to 2003 collected by the Lake Biwa Environmental Research Institute (Station L in Fig. 1) and those from 1962 to 1991 collected by the SPFES (Stations 1 to 5 in Fig. 1), as detailed in Hsieh et al. (2010). We integrated these two time series to arrive at a phytoplankton total biomass (carbon) time series (Fig. 3c). While we admit uncertainty may exist in this integration, such proxy represents the longterm variation of phytoplankton biomass in Lake Biwa. See procedure and justification in Supplement A.

\subsection{Data analysis}

Two main environmental issues were associated with the Lake Biwa ecosystem: eutrophication and warming. We investigated these environmental effects on the zooplankton community at four levels: (1) highly resolved zooplankton genus data, (2) aggregated zooplankton groups according to feeding types or a higher taxonomic level, (3) the ratio of cyclopoid/calanoid and of cladoceran/calanoid, and (4) total zooplankton abundance. The analytical procedure is illustrated in Fig. 4.

We started from the genus data (shown in Fig. 2). First, univariate correlation analyses (with a lag of up to two years considering the short generation time of zooplankton) were used to investigate long-term relationships between the environmental factors and the zooplankton abundance on an interannual scale. The stationary bootstrap approach (Politis and Romano, 1994) with an accelerated bias correction was used to compute $95 \%$ confidence limits and to perform a hypothesis test in order to account for serial dependence 


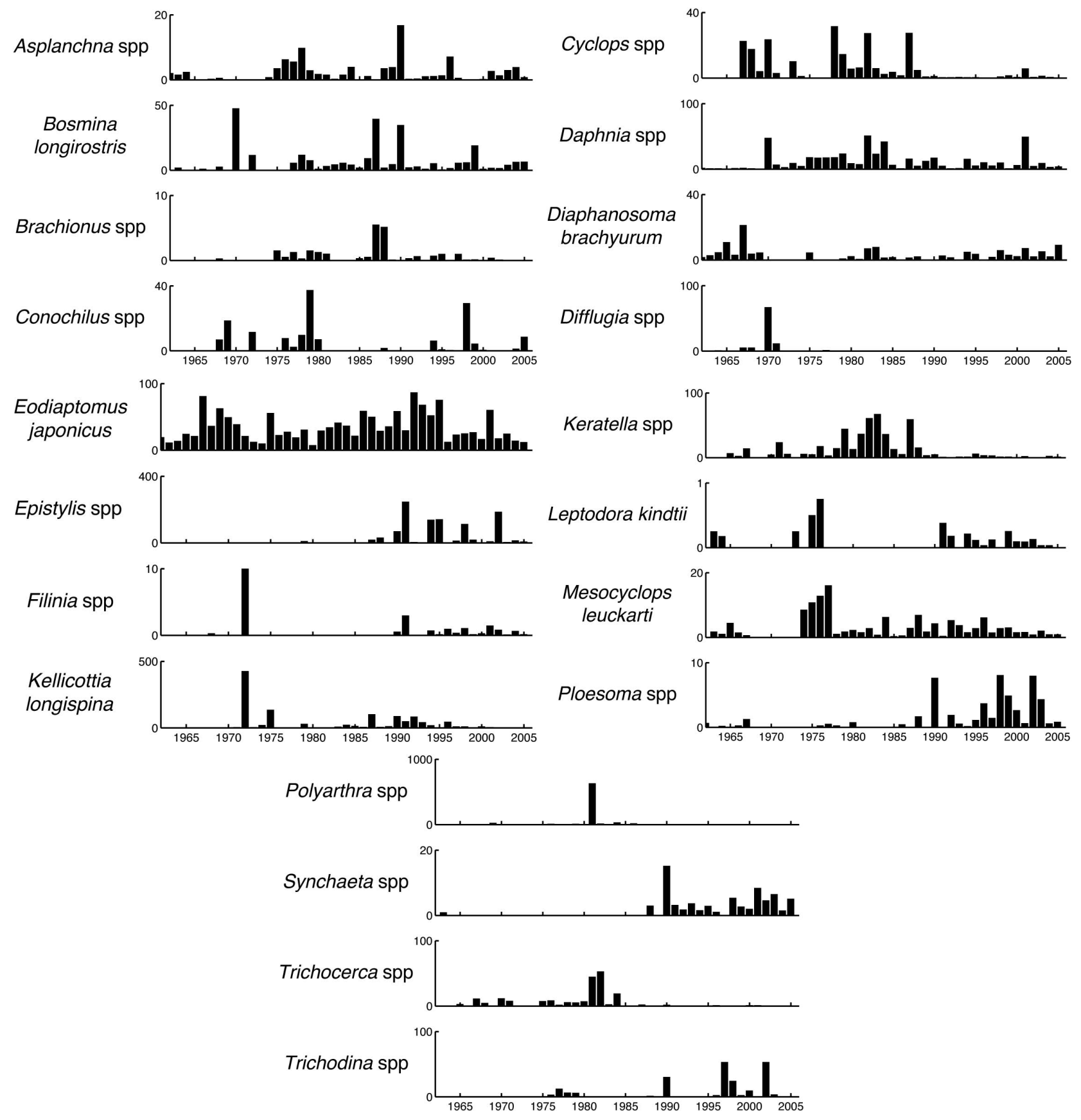

Fig. 2. Abundance $\left(10^{4}\right.$ ind. $\left.\mathrm{m}^{-2}\right)$ time series of dominant taxa. Dominant taxa are defined as taxa with occurrence $\geq 15 \mathrm{yr}$ among the 44 sampling years.

in time-series data (Hsieh et al., 2009). Second, long-term variation of zooplankton communities were examined using principal component analysis (PCA) (Legendre and Legendre, 1998). Third, we linked the temporal pattern of zooplankton community to environmental variables using redundancy analysis (RDA) (Legendre and Legendre, 1998). A stepwise procedure was used to select the significant variables (using $\alpha=0.05$ ) and to exclude irrelevant variables.
Such a procedure selects only the variables that explain the highest variance when colinearility exists among multiple variables in the model (Peres-Neto et al., 2006). Prior to PCA and RDA analyses, abundance data were transformed as $\log _{10}(\mathrm{X}+1)$ and then normalized. Finally, using a variance partition approach (Legendre et al., 2005; Cushman and McGarigal, 2002), we calculated the relative contributions of bulk environmental factors and the phytoplankton 

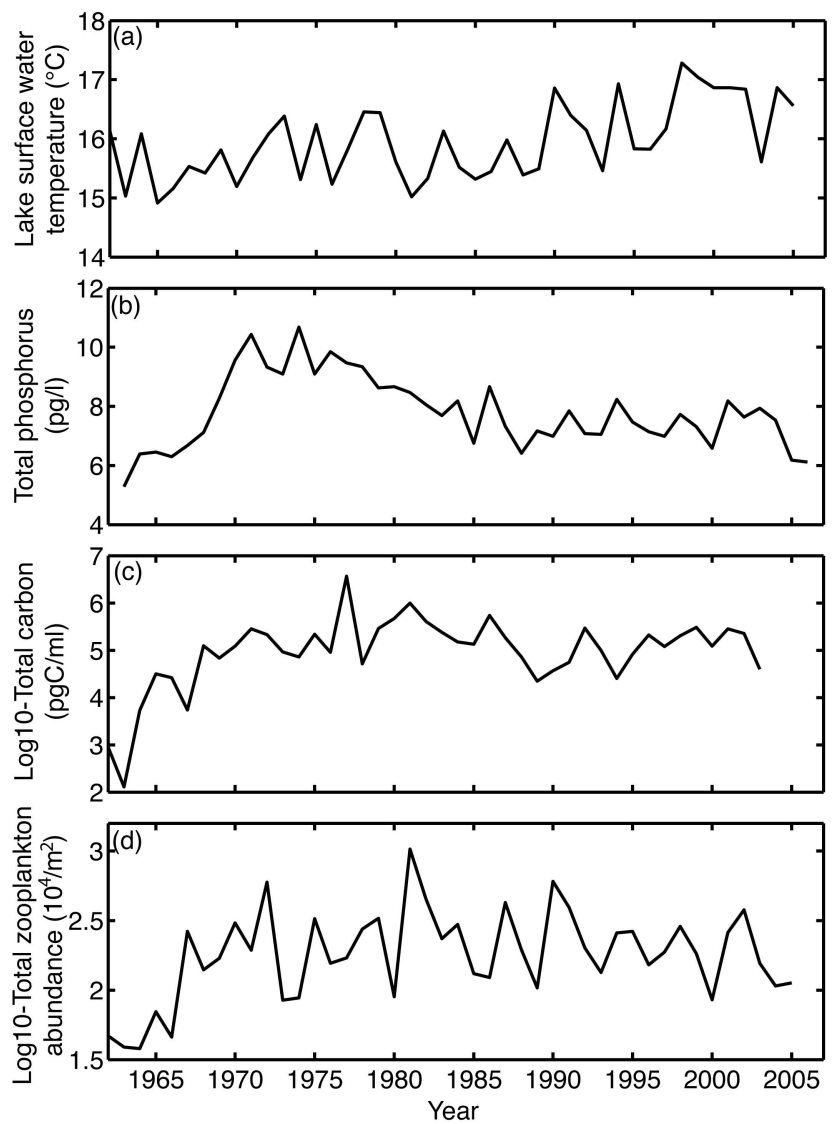

Fig. 3. Time series of (a) annual averaged lake surface water temperature and (b) estimated average total phosphorus in upper $20 \mathrm{~m}$, (c) estimated phytoplankton carbon biomass, and (d) total water column integrated zooplankton abundance averaged over 5 stations. Zooplankton abundance is significantly correlated with total phosphorus with 1-yr lag and concurrent phytoplankton carbon (stationary bootstrap test, $r=0.387$ and $r=0.534$, respectively, $p<0.05$ ).

community in explaining the temporal variation of the zooplankton community.

We tested the hypothesis that phytoplankton community can better explain the variation of zooplankton community than bulk environmental variables by a variance partition approach (Pinel-Alloul et al., 1995) and compared whether their contributions differed significantly using a randomization test (Peres-Neto et al., 2006) of 5000 times. Such tests can only apply for the data between 1978 and 2003 because detailed phytoplankton community data were only available during this period. To investigate the hypothesis, we aggregated phytoplankton community data (Supplement B) according to their size $\left(0 \sim 200 \mathrm{um}^{3}, 200 \sim 1000 \mathrm{um}^{3}, 1000 \sim\right.$ $8000 \mathrm{um}^{3}$, and $>8000 \mathrm{um}^{3}$; time series shown in Supplement Fig. B1) (Urabe et al., 1996; Makarewicz et al., 1998), morphology (single cell, filament, and colony type; time series shown in Supplement Fig. B2) (Anneville et al., 2002b; Hsieh et al., 2010), or taxonomic class (time series shown in
Supplement Fig. B3), because these traits potentially influence the trophic interactions between zooplankton and phytoplankton. For the phytoplankton community, we did not consider individual species. Rather, we aggregated phytoplankton into groups according to size, morphology, and higher taxonomy, because zooplankton unlikely have the ability to distinguish phytoplankton species.

Next, we aggregated zooplankton data according to their taxonomic groups (Supplement Fig. C1) or feeding types (Supplement Fig. C2). Detailed information on the feeding types and taxonomic groups for each taxon was collected from the literature and are provided in Supplement D. We note that feeding types and taxonomic groups are not independent. While body size is an important life history trait to consider for zooplankton (Gillooly, 2000; Hansen et al., 1997), we do not have size information of each taxon through time. The size of many crustaceans can vary substantially. Those aggregated zooplankton data were analyzed with respect to environmental variables and phytoplankton community in the same manner as aforementioned. Similarly, the ratio of cyclopoid/calanoid and of cladoceran/calanoid was analyzed likewise. Finally, for the zooplankton abundance, simple stationary bootstrap correlation was employed to see how they responded to eutrophication and warming.

\section{Results}

\subsection{Zooplankton community responding to eutrophication and warming}

The zooplankton community exhibited a substantial change from 1962 to 2005 when the data were investigated at the species-genus level (Fig. 2). The results of univariate correlation analyses indicated that several taxa were either correlated with changes in the trophic status of the lake (e.g. $C y$ clops spp., Daphnia spp., Diaphanosoma brachyurum, Eodiaptomus japonicus, Keratella spp., Mesocyclops leuckarti, Polyarthra spp., and Trichocerca spp.) or water temperature and/or the Arctic Oscillation index (e.g. Bosmina longirostris, Conochilus spp., Cyclops spp., Eodiaptomus japonicus, Epistylis spp., Keratella spp., Leptodora kindtii, Ploesoma spp., Synchaeta spp., and Trichodina spp.), although still other taxa did not show any correlation (Table 1). The results of principal component analysis revealed the long-term variation of the zooplankton community, and the first and second principal components amount to explain $35.5 \%$ of the variance (Fig. 5a and b). The first principal component showed a first peak around 1970 and a second peak around 1980, possibly influenced by eutrophication (cf. Fig. $3 \mathrm{~b}$ and c); it then changed to a negative phase around 1990 due to an increase in water temperature (cf. Fig. 3a). The second principal component also showed a first peak around 1970 and turned into a negative phase from 1974 to 1980, and has fluctuated since then. The long-term 

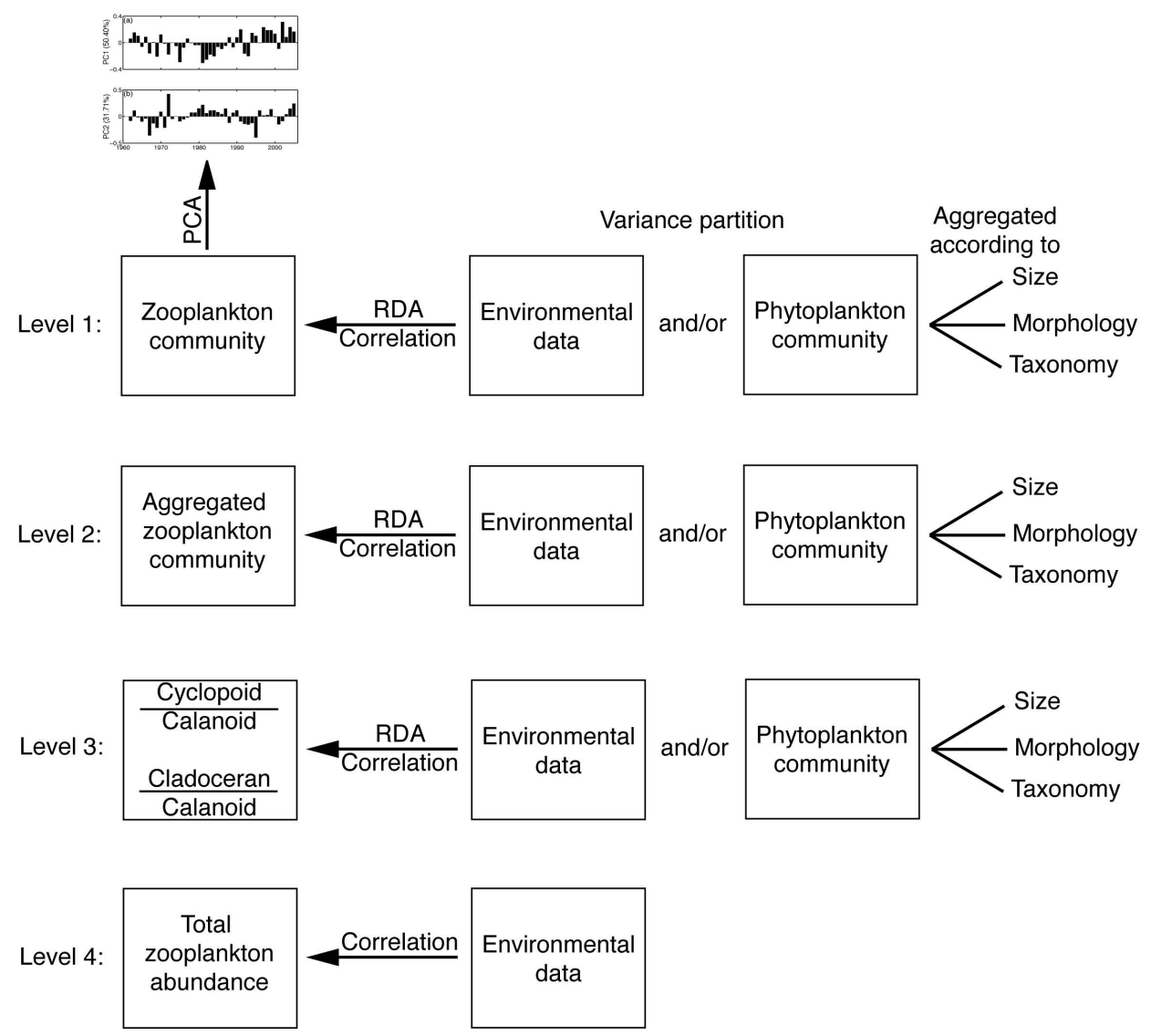

Fig. 4. Schematic illustration of the analytical procedure at various levels.

zooplankton community variation was significantly affected by environmental changes (randomization test, $p<0.05$ ), based on RDA results (Fig. 5c). The variation from early 1960s to late 1980s was related to the change in the trophic status of the Lake, while the variation from the late 1980s onwards was caused by warming. The result of RDA (Fig. 6a), based on data from 1978 to 2003, exhibited a similar pattern with that based on data from 1962 to 2005 (cf. Fig. 5c), showing that eutrophication (signified by TP) and warming have significantly driven changes in the zooplankton community.

\subsection{Responses of aggregated zooplankton to environmental variations}

When we investigated zooplankton time series aggregated according to a higher taxonomic level (Cladocera, Copepoda, Rotifera, and Protista), we found that the aggregated taxa still showed significant correlations with environmental variables (Table 2). Rotifera correlated positively with TP with a 1-yr lag and concurrent phytoplankton biomass. Cladocera showed a positive correlation with TP and PDO with a 1-yr lag and phytoplankton biomass with 2-yr lag. Copepoda did not show any correlation, and Protista correlated positively with water temperature and negatively with concurrent SOI, and TP with a 2-yr lag. Note that when lagged and concurrent correlations were all significant, we considered the correlation of the strongest strength. The results of RDA based on the aggregated taxa also revealed the effects of eutrophication and warming (Fig. 5d) similar to the RDA results based on genus data (cf. Fig. 5c); however, the gradient of increased eutrophic status and warming is less clear.

When we aggregated zooplankton data according to their feeding types (herbivorous, carnivorous, omnivorous, and parasitic), correlations between zooplankton and environmental factors were also found (Table 2). Herbivorous zooplankton correlated positively with TP with a 1-yr lag and concurrent phytoplankton biomass. Carnivorous and omnivorous zooplankton did not show any correlation; parasitic zooplankton correlated positively with water temperature. The results of RDA based on the feeding types again revealed the effects of eutrophication and warming (Fig. 5e) similar to the RDA results based on genus data (cf. Fig. 5c); however, the gradient of increased eutrophic status and warming is less clear. 
Table 1. Results of the correlation analyses between zooplankton abundance and environmental variables.

\begin{tabular}{|c|c|}
\hline Taxa & Variables \\
\hline \multicolumn{2}{|l|}{ Asplanchna spp. } \\
\hline Bosmina longirostris & -LST lag 2 yr \\
\hline \multicolumn{2}{|l|}{ Brachionus spp. } \\
\hline Conochilus spp. & $+\mathrm{LST}$ \\
\hline Cyclops spp. & +Phyto lag $1 \mathrm{yr},-$ LST lag 2 yr \\
\hline Daphnia spp. & +TP, +Phyto lag 2 yr \\
\hline Diaphanosoma brachyurum & -TP lag 2 yr, -Phyto \\
\hline \multicolumn{2}{|l|}{ Difflugia spp. } \\
\hline Eodiaptomus japonicus & $-\mathrm{TP}$ lag $2 \mathrm{yr},+\mathrm{AO}$ \\
\hline Epistylis spp. & +LST, +AO lag $1 \mathrm{yr},-$ SOI \\
\hline \multicolumn{2}{|l|}{ Filinia spp. } \\
\hline \multicolumn{2}{|l|}{ Kellicottia longispina } \\
\hline Keratella spp. & $\begin{array}{l}\text { +TP lag } 1 \mathrm{yr},+ \text { +Phyto lag } 2 \mathrm{yr} \\
\text {-LST lag } 2 \mathrm{yr},+ \text { +PDO lag } 2 \text { yr }\end{array}$ \\
\hline Leptodora kindtii & $\begin{array}{l}\text { +LST lag } 1 \mathrm{yr},+ \text { AO lag } 2 \mathrm{yr}, \\
\text {-PDO }\end{array}$ \\
\hline Mesocyclops leuckarti & +TP lag 1yr \\
\hline Ploesoma spp. & $+\mathrm{LST},+\mathrm{AO}$ lag $2 \mathrm{yr}$ \\
\hline Polyarthra spp. & +Phyto \\
\hline Synchaeta spp. & +LST, +AO lag $1 \mathrm{yr}$ \\
\hline Trichocerca spp. & +TP lag 1 yr, +Phyto lag $1 \mathrm{yr}$ \\
\hline Trichodina spp. & +LST, +SOI lag 2 yr \\
\hline
\end{tabular}

Note: only significant variables are shown (based on stationary bootstrap test with $\alpha=0.05)$. + indicates a positive correlation, - indicates a negative correlation, and lag $1 \mathrm{yr}$ indicates that the zooplankton response is one year behind. If 0,1 , and $2 \mathrm{yr}-\mathrm{lag}$ correlations are significant, only the best fit is retained. The results are not adjusted for multiple tests because we wish to explore potential relationships between zooplankton abundances and environmental variables. While correlation exists, the average explained variance is less than $15 \%$. LST, Lake Surface water Temperature; TP, Total Phosphorus; Phyto, phytoplankton carbon biomass, AO, Arctic Oscillation; PDO, Pacific Decadal Oscillation; SOI, Southern Oscillation Index.

\subsection{Ratio of cladoceran/calanoid and of cyclopoid/calanoid and the total zooplankton abundance as an indicator of eutrophication}

The ratio of cladoceran/calanoid (Fig. 7a) and of cyclopoid/calanoid (Fig. 7b) may be indicative of the trophic status of the lake. The cladoceran/calanoid ratio correlated positively with TP with a 2-yr lag and phytoplankton biomass with a 1-yr lag, and the ratio of cyclopoid/calanoid correlated positively with concurrent TP with a 2-year lag and the phytoplankton biomass with a 1-yr lag (Table 3). The total zooplankton abundance (Fig. 3d) correlated positively with TP with a 1-yr lag and concurrent phytoplankton biomass (stationary bootstrap test, $p<0.05$ ).

\subsection{Differential effects of environmental variables and phytoplankton community on zooplankton}

We tested the hypothesis, whether phytoplankton community can better explain the variation of zooplankton community than bulk environmental variables, by comparing their rel- ative contributions in explaining the temporal variation of the zooplankton community. For this investigation, we used only data from 1978 to 2003 , when phytoplankton community data were available. When considering genus-level zooplankton data, both environmental factors (mainly TP, phytoplankton biomass, and temperature) and the phytoplankton community (aggregated according to their size, morphology, and taxonomic class) explained a significant amount of variance (Table 4). Together, these two matrices explained $>50 \%$ of zooplankton variance. The environmental variables explained $38.05 \%$ of variance, and the phytoplankton community explained $15.69 \%$ to $38.05 \%$ of the variance depending on how phytoplankton data were aggregated. Still, a significant common fraction existed between the environmental variables and the phytoplankton community. When we partitioned the variance, the environmental variables explained slightly higher variance than the the phytoplankton data aggregated into either size or morphological groups, whereas the phytoplankton class-level data explained slightly higher variance than the environmental variables (Table 4). However, the difference is not statistically different $(0.11<$ $p<0.67)$. The best combination of explanatory variables consisted of the environmental matrix and class-level phytoplankton data, which explained $72.1 \%$ of variance. The most parsimonious RDA results based on forward selection are shown in Fig. 6b, and only temperature and biomasses of Cryptophyceae and Cyanobacteria were retained in the final model.

When considering the zooplankton feeding groups, the environmental variables explained a significant amount of variance $(38.8 \%)$, but the phytoplankton community explained only a small amount of variance, except for class-level phytoplankton data (Table 5). Together, these two matrices explained $50 \%$ of zooplankton variance. When we partitioned the variance, the environmental variables explained higher variance than phytoplankton data; however, the difference remained statistically insignificant $(0.13<p<0.29)$. Similar results were found when considering the zooplankton taxonomic groups (Table 5).

The ratio of cladoceran/calanoid was better explained by the phytoplankton matrix than the environmental matrix, but the difference remained statistically insignificant $(0.34<$ $p<0.56$ ) (Table 6). The phytoplankton community explained a significant amount of variance (46.52-52.49\%), and the environmental variables explained $28.41 \%$ of variance. Together, these two matrices explained $>60 \%$ of the variance. The ratio of cyclopoid/calanoid was also better explained by the phytoplankton matrix (40.9-68.84\%) than the environmental matrix (36.34\%), except for the comparison of environmental variables versus phytoplankton morphological groups (Table 6). However, the difference was statistically insignificant $(0.15<p<0.87)$. Together, these two matrices explained $>50 \%$ of the variance. Similar to the results based on the genus data, the best combination included the environmental variables and class-level 

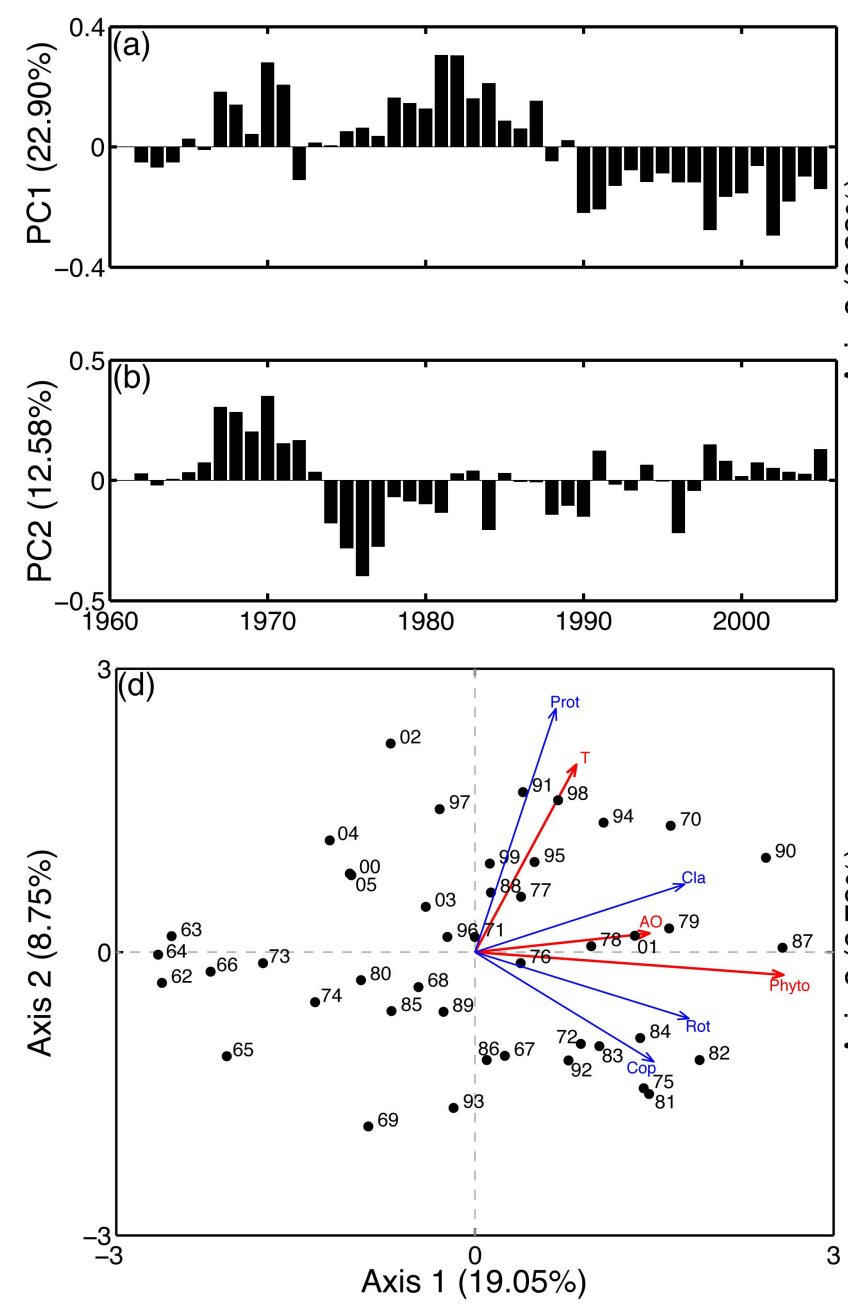
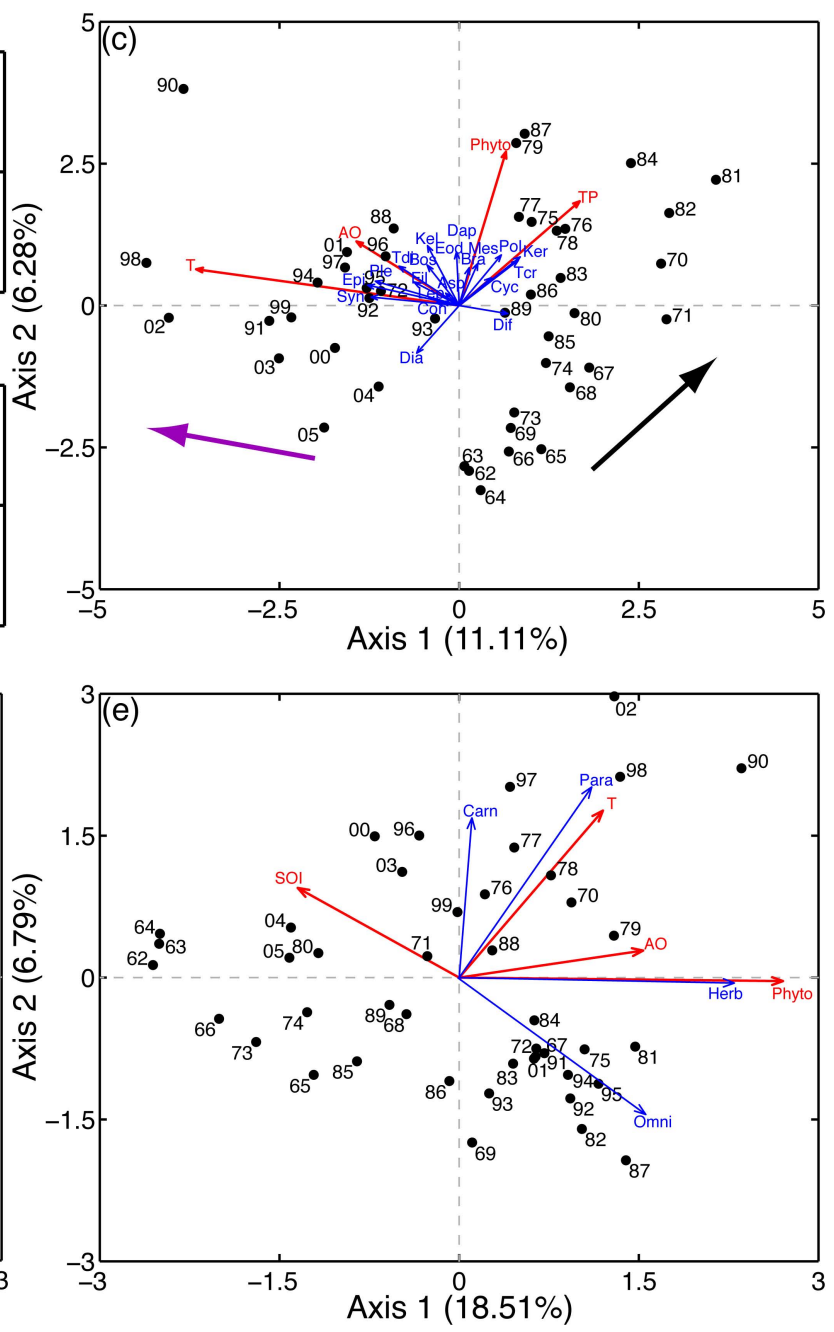

Fig. 5. Principal component analysis of dominant taxa (a and $\mathbf{b})$, and biplot of redundancy analysis relating years and zooplankton taxa and depicting how environmental factors affected the zooplankton community dynamics (c-e). The analyses were based on data at (c) genus level, (d) aggregated higher taxonomic groups, and (e) aggregated feeding types. In (c), the black arrow indicates a gradient of increased eutrophic status, and the purple arrow indicates a warming gradient. In (d) and (e) the gradient of increased eutrophic status and warming is less clear.

phytoplankton data, each explaining $74.75 \%$ and $87.38 \%$ of variance for the cladoceran/calanoid and cyclopoid/calanoid ratio, respectively (Table 6).

\section{Discussion}

\subsection{The zooplankton community in response to environmental variations}

The ecosystem of Lake Biwa has experienced a dramatic change in trophic status (Fig. $3 b$ and c) and thermo regime (Fig. 3a) during the past half century. These environmental changes in turn have driven the reorganization of the zooplankton community (Figs. 2 and 5). This is particularly visible in the RDA results, where the gradient of trophic varia- tion (TP and phytoplankton biomass) and temperature variation (lake surface temperature and $\mathrm{AO}$ ) has had significant effects on the evolution of zooplankton community (Fig. 5c). These kind of effects of eutrophication-reoligophication processes and warming on zooplankton communities have also been observed in other lakes (Jeppesen et al., 2003; Stige et al., 2009; Straile and Geller, 1998; Lovik and Kjelliberg, 2003; Anneville et al., 2007).

In Lake Biwa, the total zooplankton abundance showed a significant positive correlation with TP and phytoplankton biomass (Fig. 3b, c, and d), suggesting a bottom-up control. Nevertheless, not every taxon showed a significant positive response; among the 20 taxa, only six showed a significant positive correlation to TP or phytoplankton biomass (Table 1). We further investigated whether a taxon's positive 

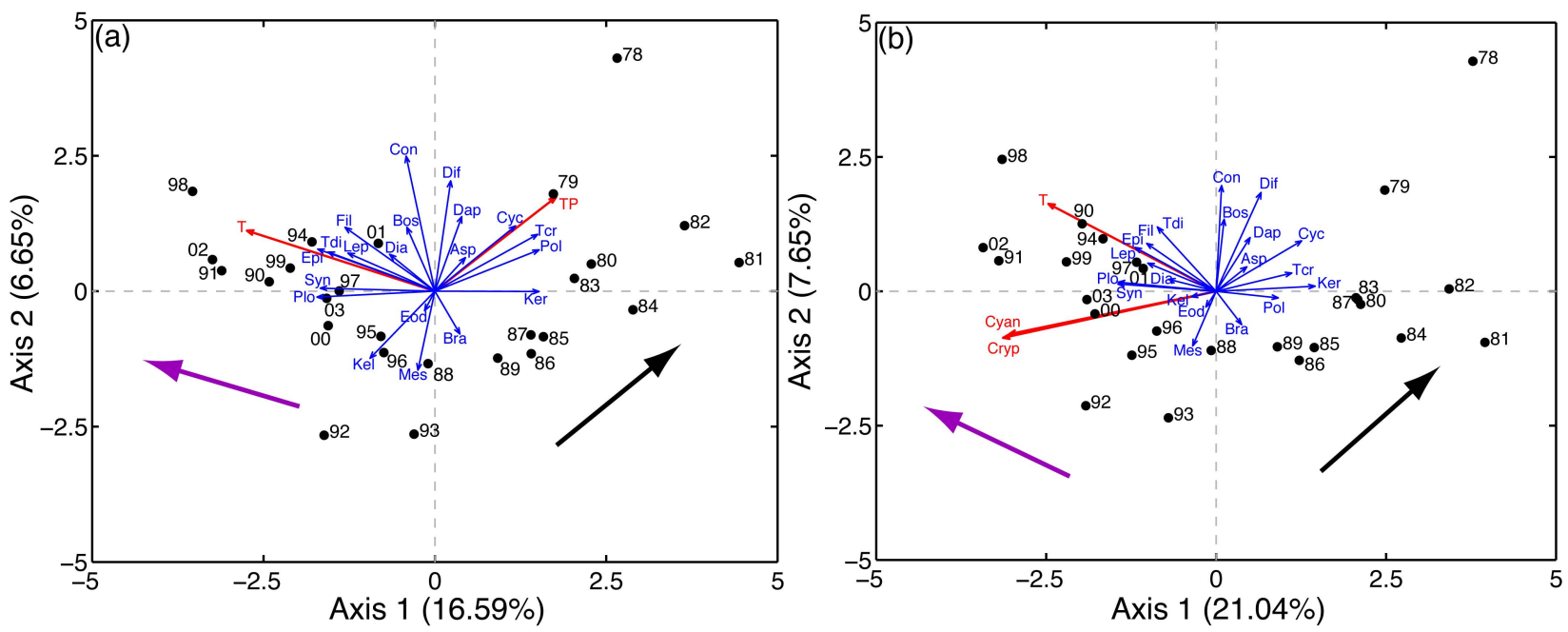

Fig. 6. Biplot of redundancy analysis relating years (1978 to 2003) and zooplankton taxa and depicting (a) how temperature and TP, and (b) how temperature, biomasses of Cryptophyceae and Cyanobacteria affected zooplankton dynamics. The black arrow indicates a gradient of increased eutrophic status, and the purple arrow indicates a warming gradient.

response to trophic status is dependent on its feeding type or taxonomy (Supplement D) and found no significant relationship (logistic regression, $p>0.4$ ). In addition to the bottom-up effects, the thermo regime also had significant effects; nine out of the 20 taxa exhibited a significant correlation (negative or positive) with temperature (Table 1). Nevertheless, whether a taxon responded to water temperature is not dependent on its feeding type or taxonomy (logistic regression, $p>0.4)$. While warming effects on zooplankton have been widely documented (George and Harris, 1985; Molinero et al., 2007), the mechanisms underlying the complex pattern in the Lake Biwa zooplankton are far from clear. Top-down effects from planktivorous fish or other invertebrates in the zooplankton community may also be important (Carpenter and Kitchell, 1988) but cannot be examined here due to lack of data. A future monitoring of Lake Biwa should include higher trophic levels. In addition, because water warming is accompanied by a reoligotrophication process, it may be difficult to discern the effects of trophic status and warming.

Among the 20 taxa, five showed a significant correlation with AO (Table 1). This linkage is likely due to temperature effects, as AO showed a significant positive correlation with Lake Biwa water temperature (Hsieh et al., 2010). A few taxa showed a correlation with PDO or SOI (Table 1). While PDO and SOI have been shown to affect marine zooplankton through changes in circulation around Japan (Chiba et al., 2006), their effects on Japanese lake ecosystems are not known.

While 15 among the 20 taxa showed a significant correlation with the environmental variables investigated here, the strengths of all the correlations are small. We suspected that complex competition among zooplankton (Einsle, 1983) or a compensation mechanism may be at work within a trophic level (defined as herbivores, carnivores, or omnivores). If compensation is important, negative covariance should prevail (Houlahan et al., 2007). Following Houlahan et al. (2007), we investigated the covariance structure among the taxa within the same trophic level using the binomial test. We found no evidence of compensation within the same trophic level. Within the herbivorous level, 31/66 pair-wise comparisons in the covariance are negative (binomial test, $p=0.712$ ), 2/6 for the carnivores (binomial test, $p=0.688$ ) and $1 / 3$ for the omnivores (binomial test, $p=1$ ). Our results echo the findings of Houlahan et al. (2007) that compensatory dynamics are not common in natural ecological communities.

Furthermore, we noted several zooplankton and phytoplankton taxa in Lake Biwa have exhibited phenological shifts during the past several decades. These shifts may cause trophic mismatch and result in community changes (Anneville et al., 2002a, b). Detailed analyses on the phenology of zooplankton is beyond the scope of this study but should be a next critical step.

\subsection{Issues on data resolution}

We investigated the issue of zooplankton data resolution by aggregating the zooplankton time series according to their taxonomy or feeding types. The aggregation according to feeding type is akin to the trait-based approach (Menezes et al., 2010). As expected, herbivorous zooplankton showed a positive response to phytoplankton biomass (Table 2). Parasitic organisms (Trichodina spp.) showed a positive relationship to temperature (Table 2), likely due to the thermo effects, that is, growth of poikilotherms depends on temperature and 
Table 2. Results of correlation analyses of zooplankton abundances, categorized according to their feeding types and taxonomic order versus environmental variables.

\begin{tabular}{|c|c|c|c|c|c|c|}
\hline & $\begin{array}{r}\mathrm{TP} \\
\left(\mathrm{ug} l^{-1}\right)\end{array}$ & $\begin{array}{r}\text { Phytoplankton biomass } \\
\left(\log _{10} \mathrm{pgC}\right)\end{array}$ & $\begin{array}{l}\mathrm{LST} \\
\left({ }^{\circ} \mathrm{C}\right)\end{array}$ & $\mathrm{AO}$ & PDO & SOI \\
\hline \multicolumn{7}{|c|}{ Taxanomic order } \\
\hline Rotifera & 0.214 & $0.323^{1}$ & -0.129 & 0.000 & 0.130 & -0.099 \\
\hline Cladocera & $0.299^{1}$ & $0.268^{1}$ & 0.084 & 0.111 & 0.107 & -0.130 \\
\hline Copepoda & 0.137 & 0.215 & -0.082 & 0.285 & 0.188 & -0.198 \\
\hline Protista & -0.005 & 0.033 & $0.433^{1}$ & 0.212 & 0.004 & $-0.245^{1}$ \\
\hline \multicolumn{7}{|l|}{ Lag $1 \mathrm{yr}^{2}$} \\
\hline Rotifera & $0.361^{1}$ & $0.262^{1}$ & -0.163 & -0.090 & 0.054 & 0.101 \\
\hline Cladocera & 0.219 & $0.286^{1}$ & -0.085 & -0.060 & $0.240^{1}$ & -0.035 \\
\hline Copepoda & 0.052 & 0.136 & -0.224 & 0.014 & 0.111 & -0.200 \\
\hline Protista & -0.088 & -0.017 & $0.326^{1}$ & 0.355 & 0.074 & -0.172 \\
\hline \multicolumn{7}{|l|}{ Lag $2 \mathrm{yr}^{2}$} \\
\hline Rotifera & 0.232 & 0.191 & -0.047 & -0.130 & 0.034 & 0.062 \\
\hline Cladocera & 0.077 & $0.381^{1}$ & -0.182 & -0.211 & 0.073 & 0.140 \\
\hline Copepoda & -0.166 & 0.086 & -0.282 & 0.034 & 0.013 & -0.066 \\
\hline Protista & $-0.279^{1}$ & 0.037 & 0.005 & 0.245 & 0.131 & 0.186 \\
\hline \multicolumn{7}{|c|}{ Feeding type } \\
\hline Herbivorous & 0.227 & $0.337^{1}$ & 0.056 & 0.092 & 0.133 & -0.218 \\
\hline Carnivorous & 0.225 & 0.043 & -0.045 & 0.065 & -0.143 & 0.183 \\
\hline Omnivorous & 0.137 & 0.215 & -0.082 & 0.285 & 0.188 & -0.198 \\
\hline Parasitic & -0.068 & 0.134 & $0.389^{1}$ & 0.161 & 0.170 & -0.192 \\
\hline \multicolumn{7}{|l|}{ Lag $1 \mathrm{yr}^{2}$} \\
\hline Herbivorous & $0.323^{1}$ & $0.268^{1}$ & -0.026 & 0.080 & 0.118 & 0.000 \\
\hline Carnivorous & 0.068 & -0.028 & -0.043 & -0.183 & -0.032 & -0.056 \\
\hline Omnivorous & 0.052 & 0.136 & -0.224 & 0.014 & 0.111 & -0.200 \\
\hline Parasitic & -0.020 & 0.124 & 0.143 & 0.039 & 0.033 & 0.161 \\
\hline \multicolumn{7}{|l|}{ Lag $2 \mathrm{yr}^{2}$} \\
\hline Herbivorous & 0.121 & $0.240^{1}$ & -0.074 & -0.020 & 0.106 & 0.125 \\
\hline Carnivorous & -0.094 & 0.045 & -0.099 & -0.188 & -0.083 & 0.146 \\
\hline Omnivorous & -0.166 & 0.086 & -0.282 & 0.034 & 0.013 & -0.066 \\
\hline Parasitic & -0.141 & 0.076 & 0.139 & -0.051 & 0.031 & $0.281^{1}$ \\
\hline
\end{tabular}

\footnotetext{
1 Significant correlation based on a stationary bootstrap test with $\alpha=0.05$. The results are not adjusted for multiple tests because we wished to explore potential relationships between zooplankton group abundances and environmental variables.

2 We investigated delayed responses of zooplankton; however, we included only 1 and 2 yr lagged correlation, considering the short generation time of zooplankton.
}

thus parasites may be more productive in warm water, as they do not have food limitation. Carnivorous and omnivorous zooplankton did not show a clear response to changes in trophic status, although carnivorous zooplankton indeed peaked in 1970 when eutrophication was serious (Table 2 and Supplement Fig. C2b). The omnivores fluctuated but maintained long-term constancy (Supplement Fig. C2c). When aggregation was done based on taxonomy, we found that Rotifera (Supplement Fig. C1a) and Cladocera (Supplement Fig. C1b) exhibited a positive correlation with phytoplank- ton biomass (Table 2). This is not surprising because most of them belong to the group of herbivores (Supplement D). Protista correlated positively with water temperature, mainly attributable to Epistylis spp. and Trichodina spp. (Fig. 2 and Supplement Fig. C1d).

While the aggregated time series (reduced resolution) still revealed a pattern of changes in trophic status and temperature regime, the community sensitivity to environmental variation was reduced. This is true for either aggregated taxonomic groups (Fig. 5d) or feeding groups (Fig. 5e). The RDA 

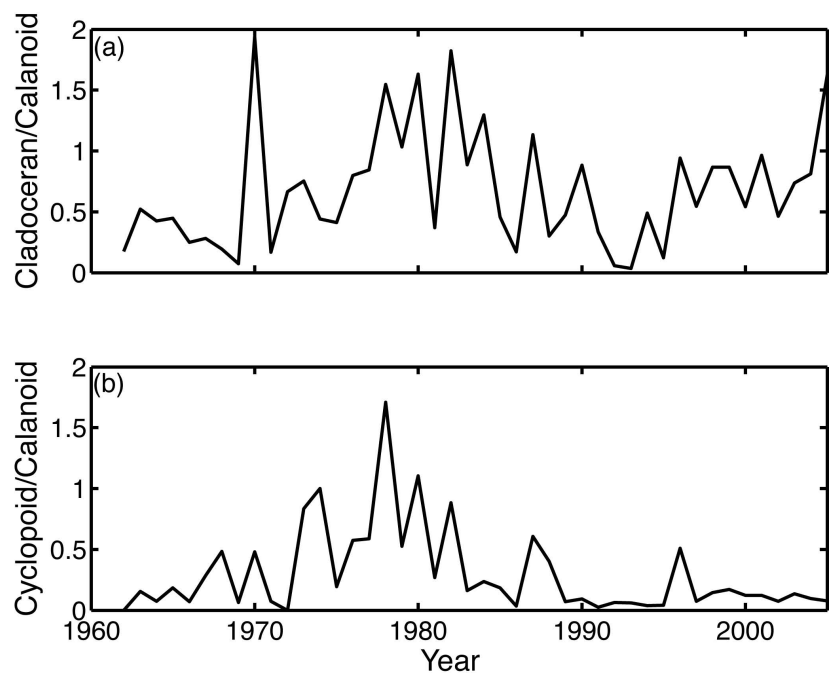

Fig. 7. Time series of the abundance ratio of (a) cladoceran/calanoid and (b) cyclopoid/calanoid.

results remained significant, but the gradient was less clear. Together with the aforementioned findings that whether a taxon responded to water temperature or trophic status is not dependent on its feeding type or taxonomy, the trait-based approach provides limited additional information in interpreting the dynamics of the Lake Biwa zooplankton.

\subsection{Zooplankton as bio-indicators of environmental changes}

The zooplankton community indeed has signaled environmental changes in Lake Biwa such as eutrophication and warming, according to the PCA (Fig. 5a and b) and RDA results (Figs. 5c-e and 6). However, the PCA and RDA scores are not ideal indicators, because the scores change whenever new data are included in updated analyses. From the genus data, we found that Cyclops spp., Keratella spp., and Trichocerca spp. showed a clear response to eutrophication and Epistylis spp., Ploesoma spp., Synchaeta spp., and Trichodina spp. showed a clear response to warming (Fig. 2 and Table 1). These taxa could potentially make good bioindicators.

The ratio of cladoceran/calanoid (Fig. 7a) and of cyclopoid/calanoid (Fig. 7b) represents a good indicator of eutrophication. This is consistent with previous studies suggesting that increasing lake trophic status will favor cyclopoid over calanoid copepods and cladocerans over calanoids (Rognerud and Kjellberg, 1984; Patalas, 1972; Straile and Geller, 1998). We noticed that these ratios generally showed a lagged response (Table 3 ). In fact, for the ratio of cladoceran/calanoid, the correlation became stronger if more lags were taken (maximal at lagged $4 \mathrm{yr}$ ). In such a case, an aggregated time series becomes informative.
Zooplankton are reasonable bio-indicators of environmental changes. Combining these data with environmental and phytoplankton data allows one to investigate the energy fluxes of the pelagic ecosystem of Lake Biwa in the context of a changing climate. For example, a steady-state box model including bacteria, phytoplankton, zooplankton, and detritus has been developed for the pelagic ecosystem of Lake Biwa using inverse methods based on limited data collected from snapshots in summer as well as some parameters from the literature (Niquil et al., 2006). Our rich data with high temporal resolution and coverage may potentially be used to investigate how energy flows change with time, and in particular, with environmental variation.

\subsection{Testing the hypothesis that the phytoplankton community explained better than bulk measurements}

We tested the hypothesis that the phytoplankton community can better explain the variation of zooplankton community than bulk environmental variables, because changes in the zooplankton community may be critically affected by change in phytoplankton community through predator-prey interactions and species competitions. However, neither our results based on genus data nor aggregated time series support this idea. Generally, the bulk of environmental variables explained slightly higher amount of variance (Tables 4 and 5). The only exception is the phytoplankton taxa, which explained an almost equal amount of variance to the bulk environmental variables (Tables 4 and 5). By contrast, for the ratio of cladoceran/calanoid and of cyclopoid/calanoid, phytoplankton community explained better (Table 6). Thus, absolute group abundances followed better with bulk variables, while ratios followed better with the phytoplankton community. However, one should note that these variance partition analyses were done based on data only from 1978 to 2003; this limited data series may have hampered our resolution of analyses. Complex predator-prey interactions and species competition play important roles in the Lake Biwa ecosystem, which warrant further studies.

\subsection{Hierarchical responses across trophic levels}

From a system point of view, the differential responses of different trophic levels to environmental changes have been suggested (Allen et al., 1987). For example, one might expect a quick response of phytoplankton biomass to TP, but a delayed response of herbivores and even a more delayed response or no response of carnivores. Such concept is biologically intuitive, although it has been rarely tested in lake ecosystems. The only comprehensive analysis was carried out in Muggelsee and revealed no such evidence (Wagner and Adrian, 2009). In Lake Biwa, the total phytoplankton biomass showed a 1-yr lagged response to TP (Hsieh et al., 2010). However, the total zooplankton abundance showed a 
Table 3. Results of correlation analyses of the zooplankton group ratio versus environmental variables.

\begin{tabular}{lllrrrr}
\hline Ratio & $\begin{array}{l}\text { TP } \\
\left(\operatorname{ug~} 1^{-1}\right)\end{array}$ & $\begin{array}{l}\text { Phytoplankton biomass } \\
\left(\log _{10} \text { pgC) }\right.\end{array}$ & $\begin{array}{r}\text { LST } \\
\left({ }^{\circ} \mathrm{C}\right)\end{array}$ & AO & PDO & SOI \\
\hline Cladoceran/calanoid & $0.246^{1}$ & 0.171 & 0.132 & -0.113 & 0.131 & -0.133 \\
Cyclopoid/calanoid & $0.448^{1}$ & $0.218^{1}$ & -0.155 & -0.186 & 0.075 & 0.088 \\
\hline Lag 1 yr & & & & & & \\
\hline Cladoceran/calanoid & $0.269^{1}$ & $0.326^{1}$ & 0.102 & -0.199 & 0.243 & -0.082 \\
Cyclopoid/calanoid & $0.429^{1}$ & $0.379^{1}$ & -0.040 & -0.158 & 0.030 & -0.064 \\
\hline Lag 2 yr & & & & & & \\
\hline Cladoceran/calanoid & $0.303^{1}$ & $0.288^{1}$ & -0.105 & -0.199 & 0.098 & 0.078 \\
Cyclopoid/calanoid & $0.542^{1}$ & 0.171 & -0.165 & -0.136 & -0.162 & 0.067 \\
\hline
\end{tabular}

${ }^{1}$ Significant correlation based on stationary bootstrap test with $\alpha=0.05$. The results have not been adjusted for multiple tests because we wish to explore potential relationships between zooplankton group abundances and environmental variables.

${ }^{2}$ We investigated delayed responses of zooplankton; however, we included only 1 and 2 yr lagged correlation, considering the short generation time of zooplankton.

Table 4. Results of variance partition to investigate the relative contribution of environmental and phytoplankton matrices in explaining the variation of zooplankton community based on genus data.

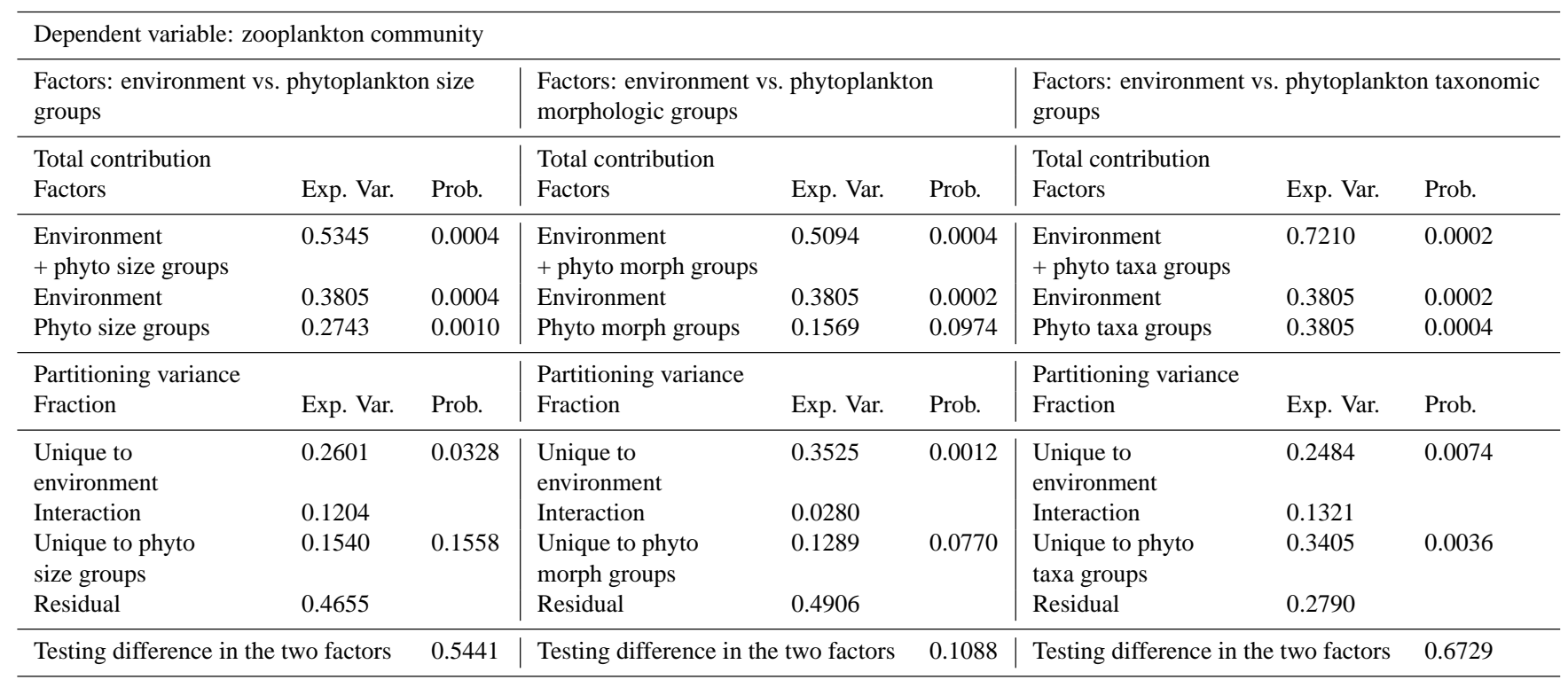

Prob.: p-value from randomizaton test of 5000 times. The interaction component cannot be tested statistically.

concurrent correlation with phytoplankton biomass but not a delayed response (Fig. 3). When taxonomic groups were considered, cladocera showed a delayed response, but other groups did not; when different trophic levels were considered, no delayed response was found (Table 2). Interestingly, while herbivores showed a significant correlation with phytoplankton biomass, the higher trophic levels (such as carnivores and omnivores) exhibited no correlation with either phytoplankton or herbivores. Particularly, omnivores showed a long-term constancy in abundance, perhaps because they could forage on a wider spectrum of food sources. These results imply the effects of external forcing dissipated through up the trophic levels, as suggested by Allen et al. (1987). Furthermore, the ratio of cladoceran/calanoid and of cyclopoid/calanoid showed a 1-yr lagged response to phytoplankton biomass (Table 3). When considering individual taxon, six taxa showed a response to phytoplankton biomass; $66.7 \%$ among them were delayed responses (Table 1). By 
Table 5. Results of variance partition to investigate the relative contribution of environmental and phytoplankton matrices in explaining the variation of zooplankton groups.

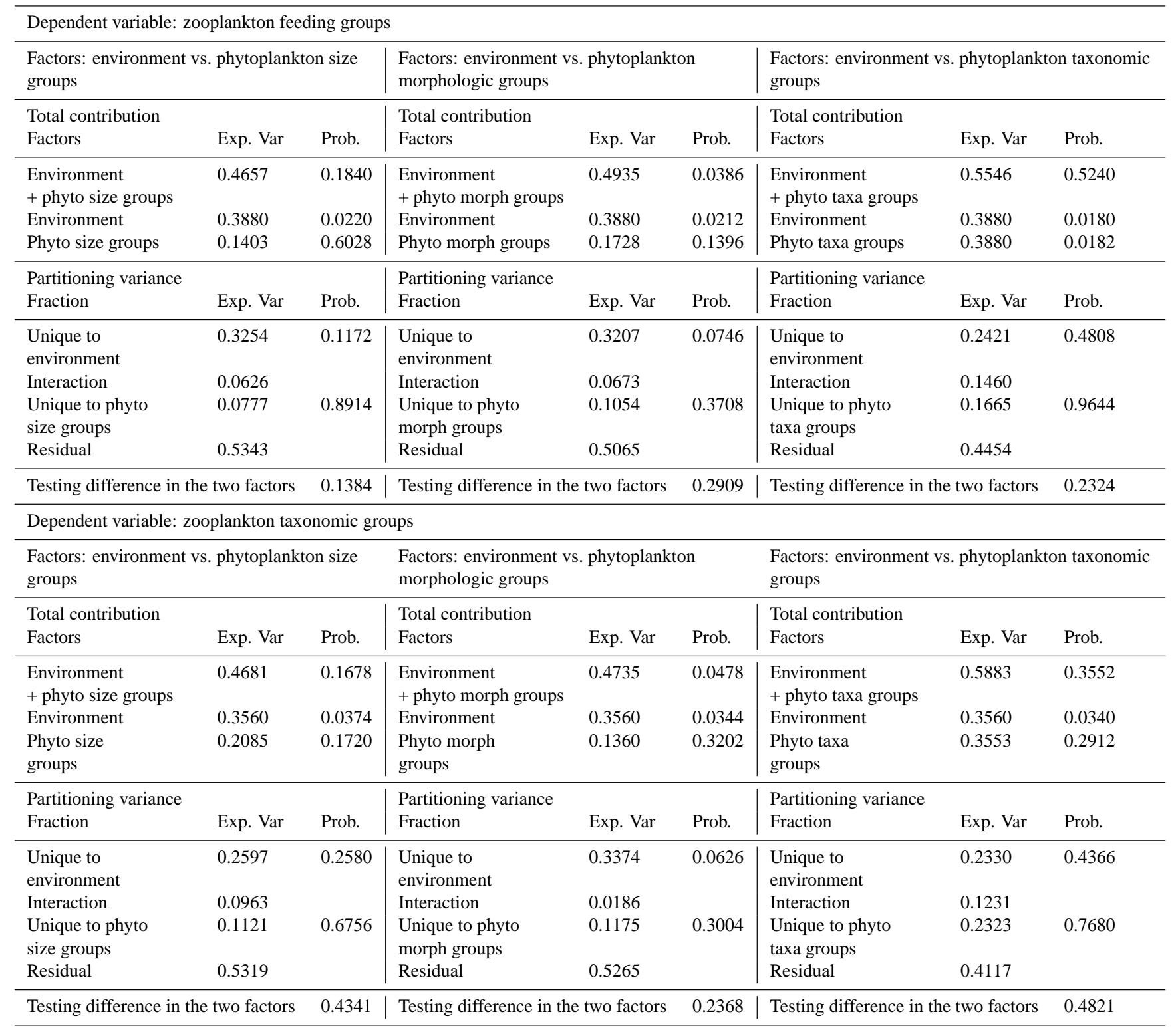

Prob.: p-value from randomizaton test of 5000 times. The interaction component cannot be tested statistically.

contrast, nine taxa showed a response to water temperature; $55.6 \%$ among them were delayed responses (Table 1). Thus for Lake Biwa, we saw some evidence of hierarchical responses across trophic levels, although the results are not unanimous. Moreover, whether or not a hierarchical response occurred may depend on the type of external forcing.

\section{Conclusions}

We compiled and analyzed long-term zooplankton community data in response to eutrophication-oligotrophication and warming in Lake Biwa. While the total zooplankton abundance showed a significant correlation with total phytoplankton biomass (Fig. 3), the zooplankton community changed substantially in response to changes in trophic status and water temperature (Figs. 5 and 6). The food (phytoplankton) availability sets the carrying capacity for the total zooplankton; however, complex interactions occurred among zooplankton taxa. Similar observations have been done for the Lake Biwa phytoplankton community in response to TP (Hsieh et al., 2010). Our analyses suggest that the Lake Biwa ecosystem exhibited a hierarchical response across trophic 
Table 6. Results of variance partition to investigate the relative contribution of environmental and phytoplankton matrices in explaining the ratio of cladoceran/calanoid and cyclop/calanoid.

\begin{tabular}{|c|c|c|c|c|c|c|c|c|}
\hline \multicolumn{9}{|c|}{ Dependent variable: cladoceran/calanoid ratio } \\
\hline \multicolumn{3}{|c|}{$\begin{array}{l}\text { Factors: environment vs. phytoplankton size } \\
\text { groups }\end{array}$} & \multicolumn{3}{|c|}{$\begin{array}{l}\text { Factors: environment vs. phytoplankton } \\
\text { morph groups }\end{array}$} & \multicolumn{3}{|c|}{$\begin{array}{l}\text { Factors: environment vs. phytoplankton taxonomic } \\
\text { groups }\end{array}$} \\
\hline \multicolumn{3}{|l|}{ Total contribution } & \multicolumn{3}{|l|}{ Total contribution } & \multicolumn{3}{|l|}{ Total contribution } \\
\hline Factors & Exp. Var & Prob. & Factors & Exp. Var & Prob. & Factors & Exp. Var & Prob. \\
\hline $\begin{array}{l}\text { Environment } \\
+ \text { phyto size groups }\end{array}$ & 0.6161 & 0.3638 & $\begin{array}{l}\text { Environment } \\
+ \text { phyto morph groups }\end{array}$ & 0.6161 & 0.3558 & $\begin{array}{l}\text { Environment } \\
+ \text { phyto taxa groups }\end{array}$ & 0.7475 & 0.0860 \\
\hline Environment & 0.2841 & 0.3298 & Environment & 0.2841 & 0.3316 & Environment & 0.2841 & 0.3150 \\
\hline Phyto size groups & 0.4652 & 0.1466 & Phyto morph groups & 0.4651 & 0.1320 & Phyto taxa groups & 0.5249 & 0.0664 \\
\hline $\begin{array}{l}\text { Partitioning variance } \\
\text { Fraction }\end{array}$ & Exp. Var & Prob. & $\begin{array}{l}\text { Partitioning variance } \\
\text { Fraction }\end{array}$ & Exp. Var & Prob. & $\begin{array}{l}\text { Partitioning variance } \\
\text { Fraction }\end{array}$ & Exp. Var & Prob. \\
\hline $\begin{array}{l}\text { Unique to } \\
\text { environment }\end{array}$ & 0.1506 & 0.6442 & $\begin{array}{l}\text { Unique to } \\
\text { environment }\end{array}$ & 0.1506 & 0.6374 & $\begin{array}{l}\text { Unique to } \\
\text { environment }\end{array}$ & 0.1249 & 0.2302 \\
\hline Interaction & 0.1335 & & Interaction & 0.1335 & & Interaction & -0.0669 & \\
\hline $\begin{array}{l}\text { Unique to phyto } \\
\text { size groups }\end{array}$ & 0.3320 & 0.3768 & $\begin{array}{l}\text { Unique to phyto } \\
\text { morph groups }\end{array}$ & 0.3320 & 0.3824 & $\begin{array}{l}\text { Unique to phyto } \\
\text { taxa groups }\end{array}$ & 0.3682 & 0.0750 \\
\hline Residual & 0.3839 & & Residual & 0.3839 & & Residual & 0.5737 & \\
\hline \multicolumn{2}{|c|}{ Testing difference in the two factors } & 0.5521 & \multicolumn{2}{|c|}{ Testing difference in the two factors } & 0.5597 & \multicolumn{2}{|c|}{ Testing difference in the two factors } & 0.3449 \\
\hline \multicolumn{9}{|c|}{ Dependent variable: cyclopoid/calanoid ratio } \\
\hline \multicolumn{3}{|c|}{$\begin{array}{l}\text { Factors: environment vs. phytoplankton size } \\
\text { groups }\end{array}$} & \multicolumn{3}{|c|}{$\begin{array}{l}\text { Factors: environment vs. phytoplankton } \\
\text { morph groups }\end{array}$} & \multicolumn{3}{|c|}{$\begin{array}{l}\text { Factors: environment vs. phytoplankton taxonomic } \\
\text { groups }\end{array}$} \\
\hline $\begin{array}{l}\text { Total contribution } \\
\text { Factors }\end{array}$ & Exp. Var & Prob. & $\begin{array}{l}\text { Total contribution } \\
\text { Factors }\end{array}$ & Exp. Var & Prob. & $\begin{array}{l}\text { Total contribution } \\
\text { Factors }\end{array}$ & Exp. Var & Prob. \\
\hline $\begin{array}{l}\text { Environment } \\
+ \text { phyto size groups }\end{array}$ & 0.5102 & 0.2050 & $\begin{array}{l}\text { Environment } \\
+ \text { phyto morph groups }\end{array}$ & 0.5514 & 0.0904 & $\begin{array}{l}\text { Environment } \\
+ \text { phyto taxa groups }\end{array}$ & 0.8738 & 0.0066 \\
\hline Environment & 0.3634 & 0.1418 & Environment & 0.3634 & 0.1478 & Environment & 0.3634 & 0.1266 \\
\hline Phyto size groups & 0.4090 & 0.0254 & Phyto morph groups & 0.2910 & 0.0582 & Phyto taxa groups & 0.6884 & 0.0118 \\
\hline $\begin{array}{l}\text { Partitioning variance } \\
\text { Fraction }\end{array}$ & Exp. Var & Prob. & $\begin{array}{l}\text { Partitioning variance } \\
\text { Fraction }\end{array}$ & Exp. Var & Prob. & $\begin{array}{l}\text { Partitioning variance } \\
\text { Fraction }\end{array}$ & Exp. Var & Prob. \\
\hline $\begin{array}{l}\text { Unique to } \\
\text { environment }\end{array}$ & 0.1012 & 0.7888 & $\begin{array}{l}\text { Unique to } \\
\text { environment }\end{array}$ & 0.2603 & 0.2270 & $\begin{array}{l}\text { Unique to } \\
\text { environment }\end{array}$ & 0.1853 & 0.0698 \\
\hline Interaction & 0.2621 & & Interaction & 0.1030 & & Interaction & 0.1865 & \\
\hline $\begin{array}{l}\text { Unique to phyto } \\
\text { size groups }\end{array}$ & 0.1469 & 0.3776 & $\begin{array}{l}\text { Unique to phyto } \\
\text { morph groups }\end{array}$ & 0.1880 & 0.1224 & $\begin{array}{l}\text { Unique to phyto } \\
\text { taxa groups }\end{array}$ & 0.5020 & 0.0054 \\
\hline Residual & 0.4898 & & Residual & 0.4486 & & Residual & 0.1262 & \\
\hline Testing difference in $t$ & two factors & 0.5873 & Testing difference in th & two factors & 0.8674 & Testing difference in & two factors & 0.1544 \\
\hline
\end{tabular}

Prob.: p-value from randomizaton test of 5000 times. The interaction component cannot be tested statistically.

levels. Higher trophic levels may show a more delayed response or no response to eutrophication than lower ones, but this kind of hierarchical response was not clear to temperature. Our results indicate that whether a taxon responded to eutrophication or warming is not dependent on its feeding type or taxonomy. Moreover, an aggregating time series based on feeding types or taxonomic groups reduced the sensitivity of using zooplankton community as bio-indicators (Fig. 5c-e). Traits other than feeding and taxonomy should be investigated in the future. However, following a classic pattern, cladoceran/calanoid and cyclopoid/calanoid abun- dance ratio (Fig. 7) was related positively to eutrophication and can be used as a good indicator. To summarize, the zooplankton community may be reasonable bio-indicators of environmental changes in Lake Biwa; however, hierarchical responses across trophic levels should be borne in mind.

Our analyses did not support the idea that the phytoplankton community can explain the variation of zooplankton community better than bulk environmental variables. In addition, we found no compensatory dynamics within a trophic level. Perhaps, complex nonlinear species competitions and predator-prey interactions prevail in Lake Biwa, 
which would hamper the linear analyses employed here. Nonlinear methods may be required to clarify complex interactions (Hsieh et al., 2008; Hsieh and Ohman, 2006).

\section{Supplementary material related to this article is available online at: http://www.biogeosciences.net/8/1383/2011/ bg-8-1383-2011-supplement.pdf.}

Acknowledgements. We thank those who have contributed to the collection of the Lake Biwa ecosystem data. Financial support was provided by a grant for Frontier and Innovative Research of National Taiwan University, National Science Council of Taiwan and by Grants-in-Aid for Scientific Research (20244079) from the Japan Society for the Promotion of Science (JSPS), the Ministry of the Environment, the Ministry of Agriculture, Forestry and Fisheries of Japan, the Japan-Taiwan Joint Research Program of Interchange Association, and a grant for Biodiversity Research of the 21st Century COE at Kyoto University. C. H. was supported by the JSPS visiting fellowship during his stay in the Lake Biwa Environmental Research Institute.

Edited by: J. Yu

\section{References}

Allen, T. F. H., O’Neill, R. V., and Hoekstra, T. W.: Interlevel relations in ecological research and management: some working principles from hierarchy theory, J. Appl. Syst. Anal., 14, 63-79, 1987.

Anneville, O. and Pelletier, J. P.: Recovery of Lake Geneva from eutrophication: quantitative response of phytoplankton, Arch. Hydrobiol., 148, 607-624, 2000.

Anneville, O., Ginot, V., Druart, J. C., and Angeli, N.: Long-term study (1974-1998) of seasonal changes in the phytoplankton in Lake Geneva: a multi-table approach, J. Plankton Res., 24, 9931007, 2002a.

Anneville, O., Souissi, S., Ibanez, F., Ginot, V., Druart, J. C., and Angeli, N.: Temporal mapping of phytoplankton assemblages in Lake Geneva: Annual and interannual changes in their patterns of succession, Limnol. Oceanogr., 47, 1355-1366, $2002 \mathrm{~b}$.

Anneville, O., Molinero, J. C., Souissi, S., Balvay, G., and Gerdeaux, D.: Long-term changes in the copepod community of Lake Geneva, J. Plankton Res., 29, 149-159, doi:10.1093/plankt/fbl066, 2007.

Benndorf, J., Kranich, J., Mehner, T., and Wagner, A.: Temperature impact on the midsummer decline of Daphnia galeata: an analysis of long-term data from the biomanipulated Bautzen Reservoir (Germany), Freshwater Biol., 46, 199-211, 2001.

Carpenter, S. R. and Kitchell, J. F.: Consumer control of lake productivity, BioScience, 38, 764-769, 1988.

Chen, Y., Qin, B., Teubner, K., and Dokulil, M. T.: Long-term dynamics of phytoplankton assemblages: Microcystis-domination in Lake Taihu, a large shallow lake in China, J. Plankton Res., 25, 445-453, doi:10.1093/plankt/25.4.445, 2003.

Chiba, S., Tadokoro, K., Sugisaki, H., and Saino, T.: Effects of decadal climate change on zooplankton over the last 50 years in the western subarctic North Pacific, Glob. Change Biol., 12, 907-920, 2006.

Cushman, S. A. and McGarigal, K.: Hierarchical, multi-scale decomposition of species-environment relationships, Landscape Ecol., 17, 637-646, 2002.

Dokulil, M. T. and Teubner, K.: Do phytoplankton communities correctly track trophic changes? An assessment using directly measured and paleolimnological data, Freshwater Biol., 50, 1594-1604, 2005.

Einsle, U.: Long-term changes in planktonic associations of crustaceans in Lake Constance and adjacent waters and their effects on competitive situations, Hydrobiologia, 106, 127-134, 1983.

Elliott, J. A., Jones, I. D., and Thackeray, S. J.: Testing the sensitivity of phytoplankton communities to changes in water temperature and nutrient load, in a temperate lake, Hydrobiologia, 559, 401-411, 2006.

Elser, J. J., Gudex, L., Kyle, M., Ishikawa, T., and Urabe, J.: Effects of zooplankton on nutrient availability and seston $\mathrm{C}: \mathrm{N}: \mathrm{P}$ stoichiometry in inshore waters of Lake Biwa, Japan, Limnology, 2, 91-100, 2001.

George, D. G. and Harris, G. P.: The effect of climate on long-term changes in the crustacean zooplankton biomass of Lake Windermere, UK, Nature, 316, 536-539, 1985.

George, D. G., Hewitt, D. P., Lund, J. W. G., and Smyly, W. J. P.: The relative effects of enrichment and climate change on the long-term dynamics of Daphnia in Esthwaite Water, Cumbria, Freshwater Biol., 23, 55-70, 1990.

Gillooly, J. F.: Effect of body size and temperature on generation time in zooplankton, J. Plankton Res., 22, 241-251, 2000.

Hampton, S. E., Izmest'Eva, L. R., Moore, M. V., Katz, S. L., Dennis, B., and Silow, E. A.: Sixty years of environmental change in the world's largest freshwater lake- Lake Baikal, Siberia, Glob. Change Biol., 14, 1947-1958, 2008.

Hansen, P. J., Bjornsen, P. K., and Hansen, B. W.: Zooplankton grazing and growth: Scaling within the 2-2,000-um body size range, Limnol. Oceanogr., 42, 687-704, 1997.

Horn, H.: The relative importance of climate and nutrients in controlling phytoplankton growth in Saidenbach Reservoir, Hydrobiologia, 504, 159-166, 2003.

Houlahan, J. E., Currie, D. J., Cottenie, K., Cumming, G. S., Ernest, S. K. M., Findlay, C. S., Fuhlendorf, S. D., Gaedke, U., Legendre, P., Magnuson, J. J., McArdle, B. H., Muldavin, E. H., Noble, D., Russell, R., Stevens, R. D., Willis, T. J., Woiwod, I. P., and Wondzell, S. M.: Compensatory dynamics are rare in natural ecological communities, P. Natl. Acad. Sci. USA, 104, 3273-3277, 2007.

Hsieh, C. H. and Ohman, M. D.: Biological responses to environmental forcing: The Linear Tracking Window hypothesis, Ecology, 87, 1932-1938, 2006.

Hsieh, C. H., Anderson, C., and Sugihara, G.: Extending nonlinear analysis to short ecological time series, Am. Nat., 171, 71-80, 2008.

Hsieh, C. H., Chen, C. S., Chiu, T. S., Lee, K. T., Shieh, F. J., Pan, J.-Y., and Lee, M. A.: Time series analyses reveal transient relationships between abundance of larval anchovy and environmental variables in the coastal waters southwest of Taiwan, Fish. Oceanogr., 18, 102-117, 2009.

Hsieh, C. H., Ishikawa, K., Sakai, Y., Ishikawa, T., Ichise, S., Yamamoto, Y., Kuo, T. C., Park, H., Yamamura, N., and Kumagai, 
M.: Phytoplankton community reorganization driven by eutrophication and warming in Lake Biwa, Aquat. Sci., 72, 467-483, 2010.

Huber, V. H., Adrian, R., and Gerten, D.: Phytoplankton response to climate warming modified by trophic state, Limnol. Oceanogr., 53, 1-13, 2008.

Jeppesen, E., Jensen, J. P., Lauridsen, T. L., Amsinck, S. L., Christoffersen, K., Søndergaard, M., and Mitchell, S. F.: Subfossils of cladocerans in the surface sediment of 135 lakes as proxies for community structure of zooplankton, fish abundance and lake temperature, Hydrobiologia, 491, 321-330, 2003.

Jin, Y. H., Kawamura, A., Jinno, K., and Berndtsson, R.: Quantitative relationship between SOI and observed precipitation in southern Korea and Japan by nonparametric approaches, J. Hydrol., 301, 54-65, doi:10.1016/j.jhydrol.2004.06.026, 2005.

Kagami, M., Yoshida, T., Gurung, T. B., and Urabe, J.: Direct and indirect effects of zooplankton on algal composition in in situ grazing experiments, Oecologia, 133, 356-363, 2002.

Kane, D. D., Gordon, S. I., Munawar, M., Charlton, M. N., and Culver, D. A.: The Planktonic Index of Biotic Integrity (P-IBI): An approach for assessing lake ecosystem health, Ecol. Indic., 9, 1234-1247, 2009.

Kawabata, K.: Ecology of Oocystis spp. in Lake Biwa: abundance, colony composition, viability, and food relations with Eodiaptomus japonicus and Daphnia longispina, Memories of the Faculty of Science, Kyoto University, 13, 41-47, 1988.

Kumagai, M.: Lake Biwa in the context of world lake problem, Verh. Internat. Verein. Limnol., 30, 1-15, 2008.

Legendre, P. and Legendre, L.: Numerical Ecology, 2nd edn., Developments in Environmental Modeling, Elsevier, Amsterdam, 853 pp., 1998.

Legendre, P., Borcard, D., and Peres-Neto, P. R.: Analyzing beta diversity: partitioning the spatial variation of community composition data, Ecol. Monogr., 75, 435-450, 2005.

Lovik, J. E. and Kjelliberg, G.: Long-term changes of the crustacean zooplankton community in Lake Mjøsa, the largest lake in Norway, J. Limnol., 62, 143-150, 2003.

Magadza, C. H. D.: Evaluation of eutrophication control in Lake Chivero, Zimbabwe, by multivariate-analysis of zooplankton, Hydrobiologia, 272, 277-292, 1994.

Makarewicz, J. C., Bertram, P., and Lewis, T. W.: Changes in phytoplankton size-class abundance and species composition coinciding with changes in water chemistry and zooplankton community structure of Lake Michigan, 1983-1992, J. Great Lakes Res., 24, 637-657, 1998.

Mantua, N. J., Hare, S. R., Zhang, Y., Wallace, J. M., and Francis, R. C.: A Pacific interdecadal climate oscillation with impacts on salmon production, B. Am. Meterol. Soc., 78, 1069-1079, 1997.

Menezes, S., Baird, D. J., and Soares, A. M. V. M.: Beyond taxonomy: a review of macroinvertebrate trait-based community descriptors as tools for freshwater biomonitoring, J. Appl. Ecol., 47, 711-719, 2010.

Miura, T. and Cai, Q. H.: Annual and seasonal occurrences of the zooplankters observed in the North Basin of Lake Biwa from 1965 to 1979, Lake Biwa Study Monogr., 5, 1-35, 1990.

Miyazaki, C. and Yasunari, T.: Dominant interannual and decadal variability of winter surface air temperature over asia and the surrounding oceans, J. Climate, 21, 1371-1386, doi:10.1175/2007JCLI1845.1, 2008.
Molinero, J. C., Anneville, O., Souissi, S., Balvay, G., and Gerdeaux, D.: Anthropogenic and climate forcing on the longterm changes of planktonic rotifers in Lake Geneva, Europe, J. Plankton Res., 28, 287-296, 2006.

Molinero, J. C., Anneville, O., Souissi, S., Laine, L., and Gerdeaux, D.: Decadal changes in water temperature and ecological time series in Lake Geneva, Europe relationship to subtropical Atlantic climate variability, Clim. Res., 34, 15-23, 2007.

Nagata, T. and Okamoto, K.: Filtering rates on natural bacteria by Daphnia longispina and Eodiaptomus japonicus in Lake Biwa, J. Plankton Res., 10, 835-850, doi:10.1093/plankt/10.4.835, 1988.

Nakazawa, T., Sakai, Y., Hsieh, C. H., Koitabashi, T., Tayasu, I., Yamamura, N., and Okuda, N.: Is the relationship between body size and trophic niche position time-invariant in a predatory fish? First stable isotope evidence, PLoS ONE, 5, e9120, doi:10.1371/journal.pone.0009120, 2010.

Nauwerck, A.: Zooplankton changes in Mondsee, Verh. Internat. Verein. Limnol., 24, 974-979, 1991.

Niquil, N., Bartoli, G., Urabe, J., Jackson, G. A., Legendre, L., Dupuy, C., and Kumagai, M.: Carbon steady-state model of the planktonic food web of Lake Biwa, Japan, Freshwater Biol., 51, 1570-1585, 2006.

Patalas, K.: Crustacean plankton and the eutrophication of St. Lawrence Great Lakes, J. Fish. Res. Board Can., 29, 1451-1462, 1972.

Peres-Neto, P. R., Legendre, P., Dray, S., and Borcard, D.: Variation partitioning of species data matrices: Estimation and comparison of fractions, Ecology, 87, 2614-2625, 2006.

Pinel-Alloul, B., Niyonsenga, T., and Legendre, P.: Spatial and environmental components of freshwater zooplankton structure, Ecoscience, 2, 1-19, 1995.

Politis, D. N. and Romano, J. P.: The stationary bootstrap, J. Am. Stat. Assoc., 89, 1303-1313, 1994.

Polli, B. and Simona, M.: Qualitative and quantitative aspects of the evolution of the planktonic populations in Lake Lugano, Aquat. Sci., 54, 303-320, 1992.

Ravera, O.: Effects of eutrophication on zooplankton, Prog. Water Technol., 12, 141-159, 1980.

Rognerud, S. and Kjellberg, G.: Realtionship between phytoplankton and zooplankton biomass in large lakes, Verh. Internat. Verein. Limnol., 22, 666-671, 1984.

Schindler, D. W.: Recent advances in the understanding and management of eutrophication, Limnol. Oceanogr., 51, 356-363, 2006.

Seebens, H., Straile, D., Hoegg, R., Stich, H., and Einsle, U.: Population dynamics of a freshwater calanoid copepod: Complex responses to changes in trophic status and climate variability, Limnol. Oceanogr., 52, 2364-2372, 2007.

Stige, L. C., Lajus, D. L., Chan, K. S., Dalpadado, P., Basedow, S. L., Berchenko, I., and Stenseth, N. C.: Climatic forcing of zooplankton dynamics is stronger during low densities of planktivorous fish, Limnol. Oceanogr., 54, 1025-1036, 2009.

Straile, D.: Meteorological forcing of plankton dynamics in a large and deep continental European lake, Oecologia, 122, 44-50, 2000.

Straile, D. and Geller, W.: Crustacean zooplankton in Lake Constance from 1920 to 1995: response to eutrophication and reoligotrophication, Adv. Limnol., 53, 255-274, 1998.

Thompson, D. W. J. and Wallace, J. M.: The Arctic Oscillation 
signature in the wintertime geopotential height and temperature fields, Geophys. Res. Lett., 25, 1297-1300, 1998.

Trenberth, K. E.: Signal versus noise in the Southern Oscillation, Mon. Weather Rev., 112, 326-332, 1984.

Tsugeki, N., Oda, H., and Urabe, J.: Fluctuation of the zooplankton community in Lake Biwa during the 20th century: a paleolimnological analysis, Limnology, 4, 101-107, 2003.

Urabe, J., Nakanishi, M., and Kawabata, K.: Contribution of metazoan plankton to the cycling of nitrogen and phosphorus in Lake Biwa, Limnol. Oceanogr., 40, 232-241, 1995.

Urabe, J., Kawabata, K., Nakanishi, M., and Shimizu, K.: Grazing and food size selection of zooplankton community in Lake Biwa during BITEX '93 Jp. J. Limnol., 57, 27-37, 1996.

Wagner, A. and Benndorf, J.: Climate-driven warming during spring destabilises a Daphnia population: a mechanistic food web approach, Oecologia, 151, 351-364, 2007.

Wagner, C. and Adrian, R.: Exploring lake ecosystems: hierarchy responses to long-term change?, Glob. Change Biol., 15, 11041115, 2009.

Wilhelm, S. and Adrian, R.: Impact of summer warming on the thermal characteristics of a polymictic lake and consequences for oxygen, nutrients and phytoplankton, Freshwater Biol., 53, 226237, 2008.

Williamson, C. E., Dodds, W., Kratz, T. K., and Palmer, M. A.: Lakes and streams as sentinels of environmental change in terrestrial and atmospheric processes, Front. Ecol. Environ., 6, 247254, doi:10.1890/070140, 2008.
Williamson, C. E., Saros, J. E., and Schindler, D. W.: Climate change: Sentinels of change, Science, 323, 887-888, doi:10.1126/science.1169443, 2009.

Winder, M. and Schindler, D. E.: Climatic effects on the phenology of lake processes, Glob. Change Biol., 10, 1844-1856, 2004.

Winder, M., Reuter, J. E., and Schladow, S. G.: Lake warming favours small-sized planktonic diatom species, P. R. Soc. B., 276, 427-435, 2009a.

Winder, M., Schindler, D. E., Essington, T. E., and Litt, A. H.: Disrupted seasonal clockwork in the population dynamics of a freshwater copepod by climate warming, Limnol. Oceanogr., 54, 2493-2505, 2009b.

Yoshida, T., Gurung, T. B., Kagami, M., and Urabe, J.: Contrasting effects of a cladoceran (Daphnia galeata) and a calanoid copepod (Eodiaptomus japonicus) on algal and microbial plankton in a Japanese lake, Lake Biwa, Oecologia, 129, 602-610, 2001a.

Yoshida, T., Kagami, M., Bahadur Gurung, T., and Urabe, J.: Seasonal succession of zooplankton in the north basin of Lake Biwa, Aquat. Ecol., 35, 19-29, 2001 b.

Yoshimizu, C., Yoshida, T., Nakanishi, M., and Urabe, J.: Effects of zooplankton on the sinking flux of organic carbon in Lake Biwa, Limnology, 2, 37-43, 2001.

Yoshimizu, C. and Urabe, J.: Role of Daphnia in the decomposition of organic matter in the surface layer of Lake Biwa, Lakes Reserviors, Res. Manage., 7, 325-330, 2002. 